\title{
SCREENING DAN ANALISIS KADAR OMEGA-3 DARI RUMPUT LAUT PULAU LOMBOK NTB
}

\author{
Erin Ryantin Gunawan* dan Dedy Suhendra \\ Program Studi Kimia, Fakultas Matematika dan Ilmu Pengetahuan Alam, \\ Universitas Mataram, Jalan Majapahit No. 62, Mataram, 83125, Indonesia \\ Email: erinryantin@unram.ac.id
}

\begin{abstract}
ABSTRAK
Penelitian ini mempunyai tujuan untuk mengidentifikasi jenis rumput laut yang mengandung omega-3 dan mengetahui kadar omega-3 dari rumput laut yang terdapat di pantai Pulau Lombok NTB. Minyak yang terdapat dalam rumput laut diekstraksi dengan metoda soxhletasi. Identifikasi dan kadar asam lemak dalam rumput laut ditentukan dengan alat GC-MS. Sembilan jenis rumput laut telah dianalisa dengan kadar air berkisar antara $42 \%-86,5 \%$. Minyak hasil ekstraksi mempunyai kadar antara 0,63\%-4,39\%. Dari ke sembilan jenis dipilih 4 jenis rumput laut yang mempunyai kadar minyak yang paling tinggi. Dua jenis rumput laut yang biasa dikonsumsi (Eucheuma Spinosum dan Eucheuma Cottoni) dan dua jenis lagi yang tidak biasa dikonsumsi (Gracilaria salicornia dan Ulva sp). Asam-asam lemak omega-3 yang dapat teridentifikasi dari keempat jenis rumput laut adalah asam linolenat, Eikosatrienoat (ETE), eikosapentaenoat (EPA) dan (dokosaheksaenoat) DHA dalam jumlah yang bervariasi. Kadar asam lemak dalam keempat jenis rumput laut berkisar antara 26,8\%-52,26\% dan kandungan omega-3 antara $1,86 \%-5,46 \%$.
\end{abstract}

Kata kunci: Pulau Lombok, rumput laut, asam lemak omega-3

\section{SCREENING AND ANALYSIS OF OMEGA-3 FROM SEAWEED IN LOMBOK ISLAND NTB}

\begin{abstract}
The objective of this research is to identify the type of seaweed that contents of omega-3 and to determine levels of omega-3 from marine seaweed Lombok Island. Identification and fatty acid content is determined by GC-MS instrument. The soxhletasi method used to extract oil from seaweed. Nine species of seaweed have been analyzed with the moisture content ranges between $42 \%-86.5 \%$ The extract oil have levels between $0,63 \%-4,39 \%$. Of the nine types of selected 4 types of seaweed that has the highest of oil content._Two types of seaweed commonly consumed (Eucheuma spinosum and Eucheuma cottoni) and two related species that do not usually consume (Gracilaria salicornia and Ulva sp). Fatty acids omega-3 that can be identified from the four types of seaweed are linolenic acid, Eikosatrienoat (été), eikosapentaenoat (EPA) and (docosahexaenoic) DHA in varying amounts $(1.86 \%-5.46 \%)$.
\end{abstract}

Keywords: Lombok Island, seaweed, omega-3 fatty acid. 


\section{PENDAHULUAN}

Kasus gizi buruk pada anak balita telah meningkat akhir-akhir ini. Kasus ini telah membangunkan pemegang kebijakan untuk dapat melihat lebih jelas bahwa anak balita sebagai sumber daya untuk masa depan ternyata mempunyai masalah yang sangat besar. Berdasarkan angka human development index (HDI), Indonesia menduduki peringkat ke 124 dari 187 negara di dunia. (http://datakesra.menkokesra.go.id, 2011). Tidak tertutup kemungkinan peringkat ini akan bergeser ke posisi lebih rendah apabila kondisi ini tidak ditangani secara cepat dan tepat.

Tingkat kesadaran tentang kesehatan yang rendah dalam suatu masyarakat harus di atasi dengan sumber daya yang ada di sekitarnya. Salah satu contoh adalah pencarian asupan gizi baru dari bahan non ekonomis atau mempunyai nilai ekonomis rendah. Laut NTB kaya akan berbagai jenis ikan dan alga (rumput laut). NTB memiliki areal pengembangan rumput laut yang mencapai 22.768 hektar dan baru dimanfaatkan sebesar 30\% (BPS NTB, 2011).

Banyak dari produk laut dalam hal ini rumput laut, mempunyai nilai ekonomi yang rendah, akan tetapi bisa dimanfaatkan untuk mendapatkan sesuatu yang berguna seperti kemungkinan mempunyai kandungan omega-3. Omega3 sebetulnya banyak dijumpai pada ikan laut. Ikan laut seperti salmon, tuna, hering dan mackerel adalah ikan dengan kandungan DHA tertinggi akan tetapi ikan-ikan ini merupakan ikan dengan nilai ekonomi yang tinggi (Rose and Connolly, 1999).

Asam lemak omega-3 merupakan asam lemak turunan dari prekursor asam lemak esensial linoleat dan linolenat. Asam lemak esensial tidak bisa dibentuk dalam tubuh dan harus dipasok langsung dari makanan. Kemudian prekursor itu masuk dalam proses elongate dan desaturate yang menghasilkan tiga bentuk asam lemak omega-3, yaitu LNA (asam alfa-linolenat), EPA (eikosapentaenoat), serta DHA (dokosaheksaenoat). DHA (C20:5) berperan utama dalam perkembangan sistem syaraf dan dapat meningkatkan kemampuan memori dan daya pembelajaran dan berfungsi juga sebagai anti-alergi. DHA dan EPA sangat diperlukan oleh tubuh, baik usia dini dalam kandungan maupun orang dewasa. Kedua asam lemak ini dilaporkan mampu mencegah timbulnya berbagai penyakit kanker, seperti kanker payudara dan prostat (Augustsson, et al., 2003; Cheng, et al., 2003) juga mencegah penyakitpenyakit kardiovaskular, seperti diabetes dan tekanan darah tinggi (Uauy dan Vahenzuela, 2000). Jenis omega-3 yang lain adalah Eikosatrienoat (ETE) yang berperan dalam metabolisme lipid.

Pada penelitian sebelumnya telah dilakukan uji kualitatif terhadap asamasam lemak yang terdapat dalam minyak dengan menggunakan alat Gas Kromatografi dan HPLC (Gunawan, et al. 2004; Gunawan et al., 2005; Suhendra et al., 2005). Kondisi optimum dari penggunaan alat GC tersebut diterapkan untuk uji kualitatif pada minyak yang berasal dari rumput laut. Rumput laut yang digunakan adalah jenis rumput laut yang biasa dikonsumsi dan tidak di konsumsi oleh masyarakat lombok.

\section{METODE PENELITIAN}

\section{Prosedur Penelitian}

\section{Preparasi sampel.}

Rumput laut dikumpulkan sesuai dengan jenisnya. Kemudian diblender dengan kecepatan tinggi. Sebagian ditimbang untuk ditentukan kadar airnya dan sebagian disimpan untuk penentuan Omega-3

\section{Penentuan kadar air sampel}

Rumput laut yang sudah diblender dikeringkan selama 20 jam pada suhu $100{ }^{\circ} \mathrm{C}$ dan selanjutnya ditimbang. 


\section{Ekstraksi trigliserida(TG) /minyak dari rumput laut}

Ekstraksi dari rumput laut dilakukan dengan menggunakan metode yang dikembangkan Cunnif (1995). dengan sedikit modifikasi. Rumput laut yang sudah diblender ditimbang dan dimasukkan ke dalam kertas saring berbentuk selongsong dan ditempatkan dalam Soxhlet lalu dialiri air. Ekstraksi dilakukan selama 6 jam diatas penangas air. Pelarut yang digunakan adalah n-heksana. Hasil ekstrak dikeringkan dengan natrium sulfat anhidrat. Setelah tidak mengandung air, hasil ekstrak diuapkan untuk menghilangkan heksana dengan evaporator pada suhu $40{ }^{\circ} \mathrm{C}$.

\section{Pemurnian trigliserida (TG)}

Pemurnian TG atau minyak dilakukan dengan menggunakan metode Jonzo, et al. (2000). Ekstrak minyak dilakukan dalam kolom kromatografi yang berisi silika gel. Kemudian dielusi menggunakan eluen campuran heksana/dietileter (87: 13, $\mathrm{v} / \mathrm{v})$.

\section{Hidrolisis trigliserida (TG)}

Sejumlah 25 g TG (telah ditambah 200 ppm buthyl hydroquinone, BTHQ) disaponifikasi menggunakan campuran $\mathrm{KOH}(5,78 \mathrm{~g})$, air $(11 \mathrm{~mL})$ dan etanol 95\% (66 mL) selama 1 jam pada suhu $60{ }^{\circ} \mathrm{C}$. Setelah saponifikasi ditambahkan $50 \mathrm{~mL}$ air suling. Materi yang tidak tersafonifikasi diekstrak menggunakan heksana. Pada materi yang tersaponifikasi (fraksi air) diasamkan hingga $\mathrm{pH} 1$ dengan menggunakan $\mathrm{HCl} 6 \mathrm{~N}$. Kemudian diekstrak kembali menggunakan heksana. Fraksi heksana yang mengandung asam-asam lemak bebas dibebaskan dari air dengan menggunakan natrium sulfat anhidrat.

\section{Screening (Uji kualitatif) dan uji kuantitatif (penentuan kadar) dari asam lemak}

Asam-asam lemak (dalam bentuk metil ester) diinjeksikan ke dalam GCMS dengan menggunakan kondisi optimum yang didapat dari penelitian sebelumnya (Gunawan et al., 2005). Suhu Injektor $280{ }^{\circ} \mathrm{C}$ and detektor $320{ }^{\circ} \mathrm{C}$. Suhu terprogram $200{ }^{\circ} \mathrm{C}$ naik $10{ }^{\circ} \mathrm{C} / \mathrm{min}$ sampai $300{ }^{\circ} \mathrm{C}$. Helium digunakan sebagai carrier gas.

\section{HASIL DAN PEMBAHASAN}

\section{Kadar Air}

Kadar air (Moisture Content) merupakan banyaknya air yang terkandung dalam bahan yang dinyatakan dalam persen basis basah (kadar air basah) atau persen basis kering (kadar air basis kering). Kadar air juga salah satu karakteristik yang sangat penting pada bahan pangan, karena air dapat mempengaruhi penampakan, tekstur, dan citarasa pada bahan pangan (Winarno, 2004). Pengeringan merupakan proses pengurangan sebagian kadar air bahan

Tabel 1. Kadar air beberapa jenis rumput laut

\begin{tabular}{|c|l|c|}
\hline No. & $\begin{array}{c}\text { Jenis rumput } \\
\text { laut }\end{array}$ & $\begin{array}{c}\text { Rata-rata } \\
\text { kadar air }(\%)\end{array}$ \\
\hline 1. & Acanthophora & 60.5 \\
\hline 2. & $\begin{array}{l}\text { Eucheuma } \\
\text { spinosum }\end{array}$ & 78 \\
\hline 3. & $\begin{array}{l}\text { Caulerpa } \\
\text { taxifolia }\end{array}$ & 62.5 \\
\hline 4. & $\begin{array}{l}\text { Gracilaria } \\
\text { salicornia }\end{array}$ & 86.5 \\
\hline 5. & Ulva sp & 73.5 \\
\hline 6. & $\begin{array}{l}\text { Gracilaria } \\
\text { verrucosa }\end{array}$ & 56.5 \\
\hline 7. & Sargassum. $\mathrm{sp}$ & 52.5 \\
\hline 8. & Sargassum. $\mathrm{sp} 2$ & 42 \\
\hline 9. & $\begin{array}{l}\text { Eucheuma } \\
\text { cottoni }\end{array}$ & 70 \\
\hline
\end{tabular}


Kadar air dari beberapa rumput laut (Tabel 1) bervariasi antara $42-86 \%$. Beberapa referensi menyebutkan kadar air rumput laut pada umumnya berkisar antara $80-100 \%$. Hal ini disebabkan karena rumput laut yang diambil sebelum pengeringan adalah rumput laut basah yang langsung diambil dari laut, sehingga memiliki kandungan air yang cukup banyak. Tetapi pada penelitian ini, sebelum dilakukan pengukuran kadar air, rumput laut dicuci bersih dan dikering anginkan sampai air pencucinya menguap. Jadi kadar air yang diukur bisa dikatakan banyaknya air yang terkandung dalam rumput laut. Dari ke sembilan jenis rumput laut, Gracilaria Salicornia mempunyai kadar air yang paling tinggi (86\%) dan Sargassum sp 2 mempunyai kadar air terendah (42\%).

\section{Ekstraksi Trigliserida (TG)}

Penentuan kadar minyak dari beberapa jenis rumput laut dilakukan dengan cara mengekstrak rumput laut yang telah diblender dengan pelarut heksana (metode soxhletasi). Pemilihan heksana sebagai pelarut non polar diharapkan dapat mengekstrak minyak secara optimal karena minyak termasuk senyawa non polar. Hasil selengkapnya dapat dilihat pada Tabel 2.

Dari ke sembilan jenis rumput laut yang diekstrak, kadar minyak yang paling tinggi terdapat dalam Euchema spinosum $(4,39 \%)$ dan yang paling rendah terdapat dalam Sargassum sp. $1(0,62 \%)$. Telah dilaporkan bahwa kadar minyak yang terdapat dalam jenis Eucheuma Cottoni yang terdapat di perairan wilayah Sabah Malaysia ialah sebesar 1,1\%. Sedangkan dalam penelitian ini didapat kadar minyak pada jenis yang sama tetapi berbeda tempat tumbuhnya yaitu sekitar 3,6\%. Perbedaan ini kemungkinan disebabkan dari cara mengekstrak minyak dari sampel rumput laut. Mantanjun et al. (2009), menggunakan rumput laut kering (kadar air 10\%) untuk mendapatkan minyak, sedangkan pada penelitian ini digunakan sampel rumput laut yang mempunyai kadar air sekitar $70 \%$. Perbedaan yang kedua dimungkinkan dari tempat tumbuhnya yang berbeda.

Tabel 2. Kadar minyak beberapa jenis rumput laut

\begin{tabular}{|c|l|c|}
\hline No. & \multicolumn{1}{|c|}{$\begin{array}{c}\text { Jenis Rumput } \\
\text { Laut }\end{array}$} & $\begin{array}{c}\text { Rata-rata kadar } \\
\text { minyak }(\%)\end{array}$ \\
\hline 1 & Acanthophora & 2.39 \\
\hline 2 & $\begin{array}{l}\text { Eucheuma } \\
\text { spinosum }\end{array}$ & 4.39 \\
\hline 3 & $\begin{array}{l}\text { Caulerpa } \\
\text { taxifolia }\end{array}$ & 1.54 \\
\hline 4 & $\begin{array}{l}\text { Gracilaria } \\
\text { salicornia }\end{array}$ & 2.52 \\
\hline 5 & Ulva sp & 3.79 \\
\hline 6 & $\begin{array}{l}\text { Gracilaria } \\
\text { verrucosa }\end{array}$ & 2.35 \\
\hline 7 & Sargassum. $\mathrm{sp}$ & 0.63 \\
\hline 8 & Sargassum. $\mathrm{sp} 2$ & 0.79 \\
\hline 9 & $\begin{array}{l}\text { Eucheuma } \\
\text { cottoni }\end{array}$ & 3.61 \\
\hline
\end{tabular}

\section{Hidrolisis trigliserida}

Trigliserida akan terhidrolisis jika dididihkan dengan asam atau basa. Hidrolisis trigliserida oleh basa kuat ( $\mathrm{KOH}$ atau $\mathrm{NaOH}$ ) akan menghasilkan suatu campuran sabun $\mathrm{K}^{+}$atau $\mathrm{Na}^{+}$dan gliserol. Hidrolisis trigliserida dengan asam akan menghasilkan gliserol dan asam-asam lemak penyusunnya. Asamasam lemak yang terbentuk, setelah diuapkan pelarutnya, ditimbang dan ditentukan kadar asam lemaknya. Gambar 1 memperlihatkan rata-rata kadar asam lemak untuk masing-masing jenis rumput laut. Kadar asam lemak yang tertinggi terkandung dalam rumput laut jenis Eucheuma spinosum $(52,26 \%)$ dan yang terendah dalam rumput laut jenis Gracilaria spinosum (26.80\%) 


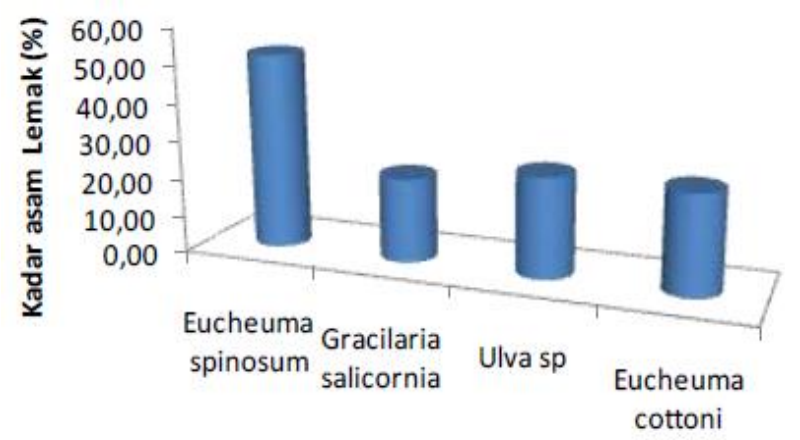

Jenis Rumput Laut

Gambar 1. Kadar asam lemak

Kadar asam lemak untuk keempat jenis rumput laut rata-rata di bawah 55\%, karena minyak rumput laut yang digunakan kemungkinan masih bercampur dengan senyawa lain dan kemungkinan campuran produk hasil reaksi hidrolisis masih mengandung sisa minyak, katalis dan air. Pada umumnya reaksi hidrolisis kurang berjalan sempurna jika tidak pada kondisi yang tepat. Untuk memperoleh asam lemak, komponen lain seperti gliserol, katalis dan sisa reaktan harus dipisahkan.

Proses ekstraksi menggunakan pelarut heksana dinilai sesuai untuk pemisahan ini karena selektivitas pelarutpelarut tertentu terhadap asam lemak dan gliserol tidak sama. Menurut Sax dan Lewis (1987) gliserol tidak larut dalam pelarut organic seperti eter, benzene dan $\mathrm{CCl}_{4}$ sedangkan asam lemak tidak larut dalam air tetapi larut dalam alkohol dan hampir semua pelarut organik termasuk pelarut hidrokarbon seperti heksana. Penggunaan dari tersier butyl hidrokuinon (TBHQ) adalah untuk mempertahankan agar ikatan rangkap (tak jenuh) pada asam lemak (yang biasa terdapat pada omega-3) tidak putus.

\section{Screening (Uji kualitatif) Asam lemak}

Untuk mengetahui komposisi asam lemak omega-3 yang terdapat dalam rumput laut digunakan alat GC dan GCMS. Gambar 2. memperlihatkan kromatogram dari omega-3 standard. Selain omega-3 jenis DHA dan EPA, terdapat pula asam lemak omega-3 jenis asam linolenat dan asam eikosatrienoat yang biasa terdapat dalam jenis algae. Puncak 1 adalah puncak dar pelarut (heksana), puncak 2 adalah puncak dari asam linolenat dengan waktu retensi (Rt) 16.375 menit dan puncak 3 adalah puncak dari asam eikosatrienoat dengan Rt 17.006 menit. Puncak 4 adalah puncak dari EPA dengan waktu retensi 17.578 menit. Puncak 3 adalah puncak dari DHA standard dengan Rt sepanjang 18.075 menit.

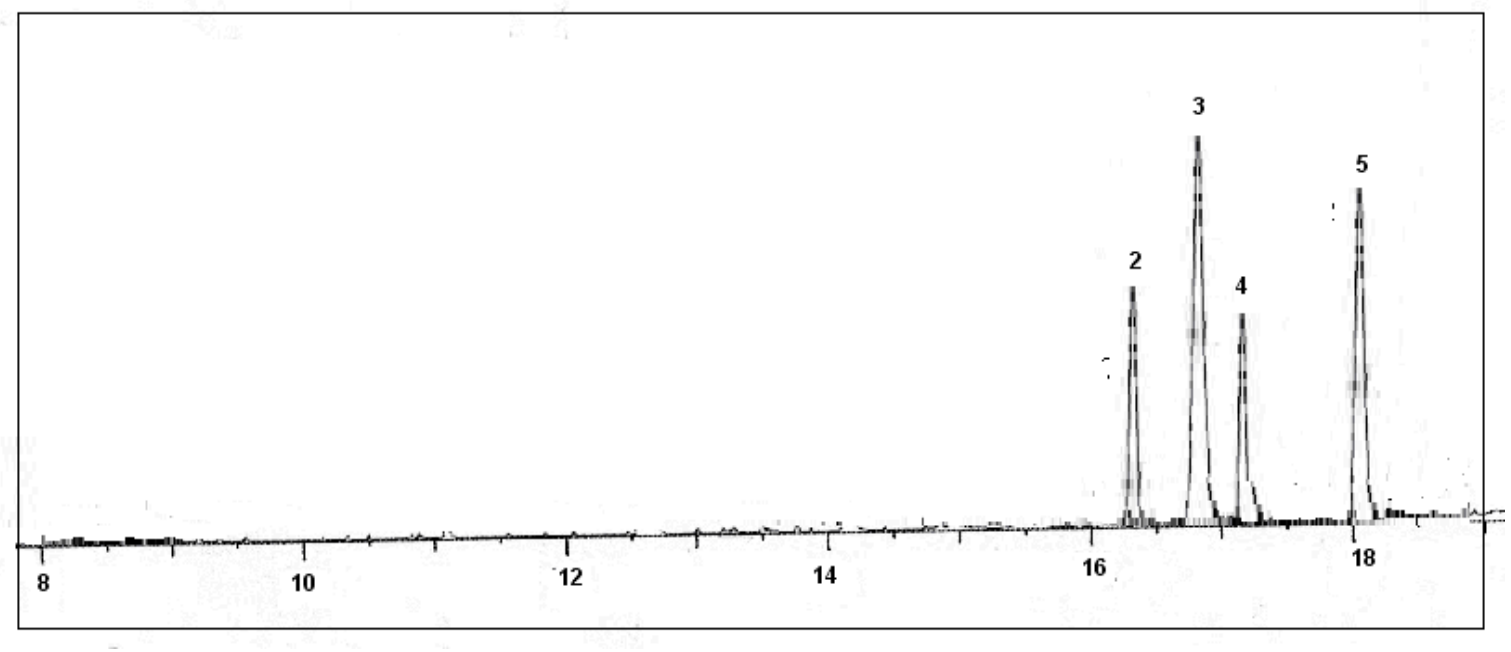

Waktu (menit)

Gambar 2. Kromatogram omega-3 standard 


\section{Euchema spinosum (EC)}

Berdasarkan hasil analisis GC-MS dari rumput laut jenis Euchema spinosum, diperkirakan ada 11 jenis asam lemak yang terkandung didalamnya (Gambar 3.) Kadar asam lemak omega-3 tertinggi yang terdapat dalam Eucheuma spinosum adalah Eikosatrienoat (1,55\%). Sedangkan jenis asam lemak omega-3 jenis DHA mempunyai kandungan $1,15 \%$ merupakan asam lemak terendah. Asam lemak omega-3 jenis lainnya yaitu jenis EPA dan linolenat berturut-turut adalah
1,43 dan 1,33\%. Kadar total dari kandungan omega-3 dalam rumput laut jenis Euchema spinosum adalah 5,46\%.

Selain asam lemak omega-3 yang terdapat dalam rumput laut Eucheuma spinosum, terdapat kandungan asam lemak palmitat dan stearat yang cukup tinggi. Menurut Matanjun et. al. (2009). Jenis Alga merah biasanya mempunyai kandungan asam palmitat dan stearat cukup tinggi cukup tinggi dibanding kandungan omega-3.

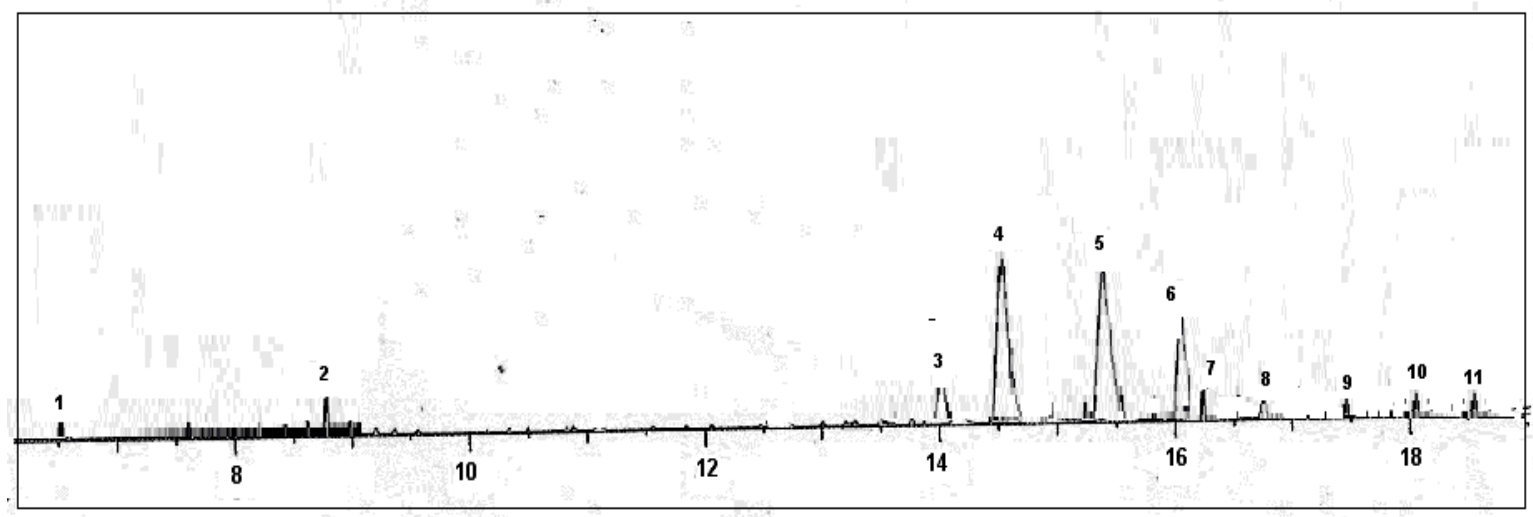

Waktu (menit)

Gambar 3. Kromatogram asam-asam lemak dari Eucheuma spinosum

\section{Gracilaria salitornia $(G S)$}

Untuk jenis rumput laut Gracilaria salitornia diperkirakan ada 11 jenis asam lemak yang dapat teridentifikasi dengan kadar Eikosatrienoat sebanyak 1,66\%. Sedangkan kandungan asam Linolenat sebesar $1.49 \%$ dan EPA sebesar 0,93\% (Gambar 4.) Kandungan total omega-3 dalam rumput laut Gracilaria salitornia adalah 4,08\%. Kadar asam lemak yang mempunyai ikatan rangkap (tak jenuh) lebih sedikit daripada kadar asam lemak yang mempunyai ikatan rangkap (jenuh). Asam lemak yang mempunyai ikatan rangkap (tak jenuh) atau polyunsaturated fatty acids (PUFA) menyebabkan minyak sangat rentan terhadap oksidasi sehingga menyebabkan ikatan rangkap dapat terputus. Proses oksidasi dapat terjadi karena beberapa hal antara lain: udara, cahaya, enzim atau logam $(\mathrm{Cu}, \mathrm{Fe})$

Proses oksidasi asam lemak Omega-3 dapat dicegah dengan cara menambahkan antioksidan. Dalam penelitian ini digunakan Tersier butyl hidrokuinon sebagai antioksidan. Tetapi ada kemungkinan penggunaan antioksidan tidak pada kondisi optimum, sehingga menyebabkan ikatan rangkap tak jenuh pada asam lemak terputus. Asam lemak omega-3 selalu mengandung ikatan rangkap tak jenuh. 


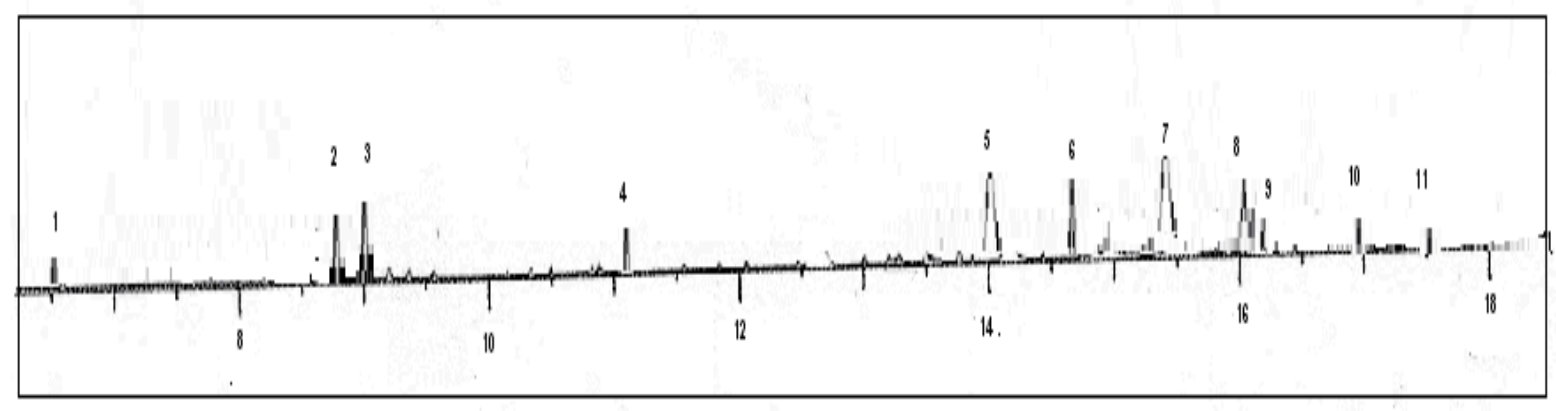

Waktu (menit)

Gambar 4. Kromatogram asam-asam lemak dari Gracilaria salitornia

\section{Ulva $\operatorname{sp}(U)$}

Rumput laut Ulva sp termasuk jenis alga hijau. Berdasarkan puncakpuncak yang teridentifikasi pada kromatogram, diperkirakan ada 10 jenis asam lemak. (Gambar 5). Kandungan tertinggi ada pada asam lemak stearat $(29.86 \%)$ dan oleat $(20.11 \%)$. Jenis omega-3 yang terdapat dal rumput laut jenis Ulva sp hanya Eikosatrienoat $(0.77 \%)$ dan EPA (1.10\%). Kandungan total omega-3 dalam rumput laut jenis Ulva sp adalah $1,86 \%$. Kandungan omega3 ini dalam rumput laut jenis ini adalah yang paling rendah diantara rumput laut jenis Eucheuma Spinosum dan Gracilaria salitornia.
Kadar asam lemak berantai pendek rata-rata lebih tinggi daripada asam lemak berantai panjang. Campuran asam-asam lemak yang telah terpisah dari produk reaksi hidrolisis terdiri atas asam lemak jenuh dan tak jenuh. Asam-asam lemak tersebut akan dipisahkan berdasarkan kelarutannya dalam solven (pelarut) tertentu. Kelarutan minyak /lemak tergantung dari polaritasnya. Asam lemak yang bersifat polar cenderung larut dalam pelarut polar dan asam lemak non polar larut dalam pelarut non polar. Sedangkan asam lemak berantai panjang cenderung tidak larut dalam air.

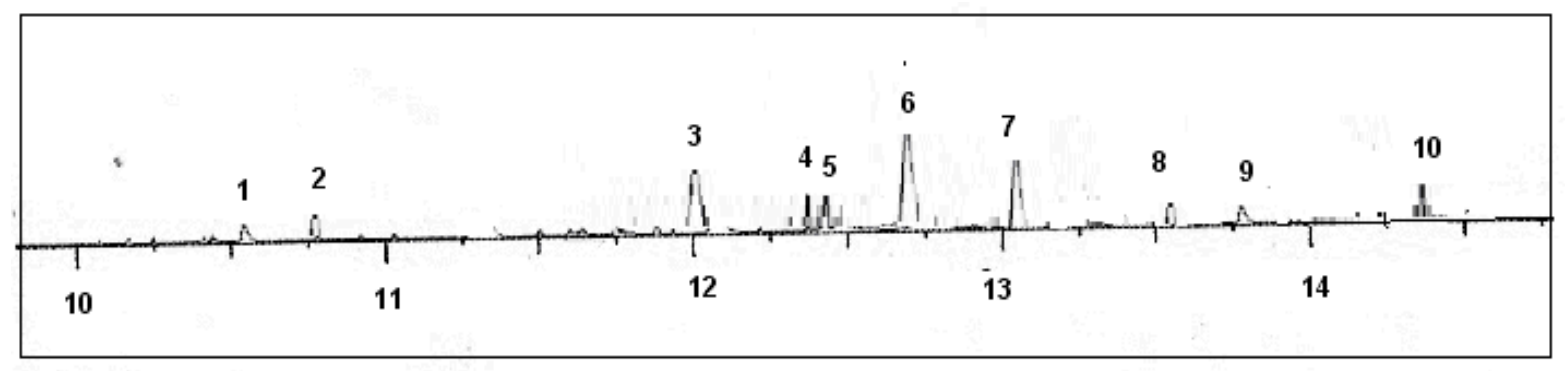

Waktu (menit)

Gambar 5. Kromatogram asam-asam lemak dari Ulva sp 


\section{Euchema Cottoni(EC)}

Gambar 6. memperlihatkan bentuk kromatogram dari asam-asam lemak yang terdapat dalam rumput laut jenis Euchema Cottoni. Terdapat 10 jenis asam-asam lemak. Untuk rumput laut jenis Euchema Cottoni, omega-3 jenis EPA mempunyai kadar yang tertinggi yaitu 2,37\%. Jenis omega-3 yang lain, Eikosatrienoat dan Linolenat berturut-turut $1,38 \%$ dan $0,91 \%$. Rumput laut jenis Euchema Cottoni juga mengandung DHA dalam jumlah yang lebih kecil yaitu $0,68 \%$. Total kandungan omega-3 adalah sebesar 5,42\%.

Rumput laut jenis Eucheuma Cottoni yang tumbuh disekitar perairan Sabah Malaysia dilaporkan mempunyai kandungan omega-3 yang cukup tinggi yaitu sebesar 45\% (Mantajun et al., 2009). Kandungan yang paling besar adalah untuk omega-3 jenis EPA. Hal ini dapat disebabkan jenis Eucheuma Cottoni yang digunakan berbeda berdasarkan spesiesnya atau proses hidrolisis yang kurang sempurna.

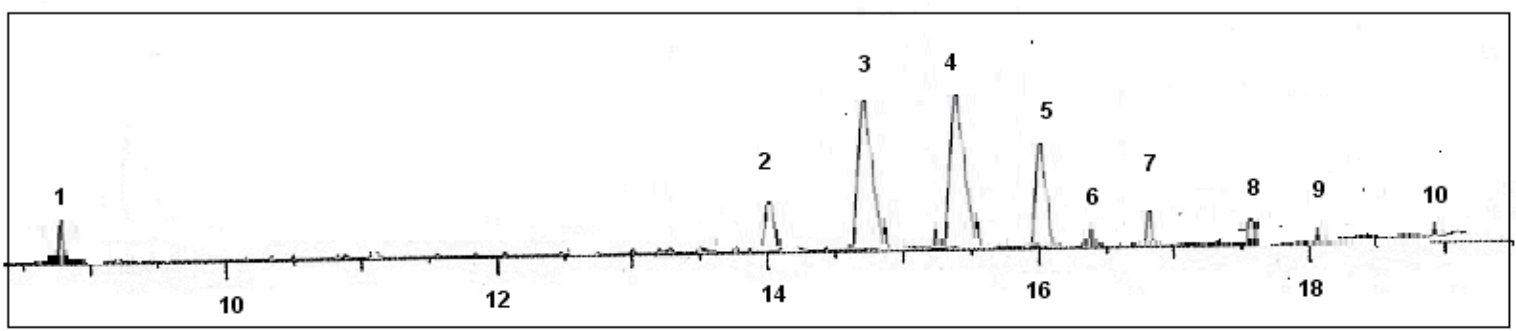

Waktu (menit)

Gambar 6. Kromatogram asam-asam lemak dari Euchema Cottoni

Tabel 3. Komposisi asam lemak yang terkandung dalam rumput laut

\begin{tabular}{|c|c|c|c|c|}
\hline \multirow{2}{*}{ Jenis asam lemak } & \multicolumn{4}{|c|}{ Kadar asam lemak (\%) } \\
\hline & ES & $\mathrm{GC}$ & $\mathrm{U}$ & $\mathrm{EC}$ \\
\hline Undecanoat & 2.84 & 3.21 & - & - \\
\hline Laurat & 5.47 & 5.42 & - & 1.86 \\
\hline Tridecanoat & - & 6.37 & - & - \\
\hline Miristat & - & 4.03 & 3.09 & - \\
\hline Myristoleat & - & - & 4.64 & - \\
\hline Pentadecanoat & 7.32 & 14.21 & 18.36 & 9.50 \\
\hline Palmitat & 34.04 & 24.27 & 9.17 & 34.83 \\
\hline Palmitoleat & - & - & 9.81 & \\
\hline Heptadecanoat & - & 14.85 & - & - \\
\hline Stearat & 25.87 & - & 35.14 & 33.73 \\
\hline Oleat & 17.59 & 23.56 & 20.11 & 13.76 \\
\hline Linolenat & 1.33 & 1.49 & - & 0.91 \\
\hline ETE & 1.55 & 1.66 & 0.77 & 1.38 \\
\hline EPA & 1.33 & 0.93 & 1.10 & 2.37 \\
\hline DHA & 1.55 & - & - & 0.68 \\
\hline Lignocerat & 1.33 & - & 3.10 & 0.98 \\
\hline
\end{tabular}

Ket. Euchema spinosum (EC), Gracilaria salitornia (GS), Ulva sp. (U), Euchema Cottoni (EC) 
$\begin{array}{lrrr}\text { Berdasarkan } & \text { Tabel } 3 & \text { terlihat } \\ \text { bahwa } & \text { asam-asam } & \text { lemak } & \text { jenuh }\end{array}$ mempunyai kandungan yang lebih tinggi dibandingkan asam-asam lemak tak jenuh. Kelarutan asam lemak lebih tinggi dari komponen gliseridanya. Asam-asam lemak tersebut larut dalam pelarut organik polar maupun non polar. Makin panjang rantai karbon pada trifiseridanya maka kelarutan minyak/lemaknya makin rendah. Asam lemak yang tak jenuh lebih mudah larut dibanding asam lemak jenuh dengan panjang rantai yang sama, dengan demikian asam lemak yang derajat ketidakjenuhannya lebih tinggi lebih mudah larut.

Tabel 3 menunjukkan perbedaan dan persaman kandungan asam-asam lemak pada keempat jenis rumput laut. Khususnya perbedaan dan persamaan dalam hal kandungan omega-3. Semua rumput laut mengandung omega-3 jenis Eikosatrienoat dan eikosapentaenoat. Asam lemak omega-3 jenis linolenat tidak terdapat dalam rumput laut jenis Ulva sp. Asam lemak DHA terdapat dalam rumput laut jenis Eucheuma, baik pada Eucheuma spinosum maupun Eucheuma cottoni walaupun dalam jumlah sedikit.

\section{KESIMPULAN}

Asam-asam lemak yang dapat teridentifikasi dari keempat jenis rumput laut yang mempunyai kadar lemak tertinggi adalah asam linolenat, Eikosatrienoat (ETE), eikosapentaenoat (EPA) dan (dokosaheksaenoat) DHA dalam jumlah yang bervariasi dan kandungan omega-3 yang terdapat dalam keempat jenis rumput laut adalah berkisar antara $1,86 \%-5,46 \%$.

\section{UCAPAN TERIMA KASIH}

$\begin{array}{lcrr} & \text { Terimakasih diucapkan } & \text { kepada } \\ \text { Direktur DP2M Direktorat } & \text { Jendral } \\ \text { Pendidikan } & \text { Tinggi, } & \text { Departemen }\end{array}$

Pendidikan Nasional yang telah membiayai penelitian ini melalui skim Hibah Bersaing (2009/2010)

\section{DAFTAR PUSTAKA}

Augustsson, K., Michaud, D.S., Rimm, E.B., Leitzmann, M.F., Stampfer, M.J., Willett, W.C., Giovannucci, E., 2003, A prospective study of intake of fish and marine fatty acids and prostate cancer, Cancer Epidemiol. Biomar. Prev. No.12, 64-67

Badan Pusat Statistik, Bappeda Provinsi NTB, 2011, NTB Dalam Angka

Cheng, J., Ogawa, K., Kuriki, K., Yokoyama, Y., Kamiya, T., Seno, K.,Okuyama, H., Wang, J., Luo, C., Fujii, T., Ichikawa, H., Shirai, T.,Tokudome, S. ,2003, Increased intake of $\mathrm{n}-3$ polyunsaturated fatty acids elevates the level of apoptosis in the normal sigmoid colon of patients polypectomized for adenomas/tumor, Cancer Lett., No.193, 17-24

Cunnif. P., 1995, Official Methods of Association of Official Analityca, edisi 16, AOAC International, Chapter 41, 17-21

F. G Winarno, 2004, Kimia Pangan dan Gizi Jakarta: Gramedia, 25-26

Gunawan E.R, M. Basri, M.B.A. Rahman, R.N.Z.A. Rahman and A.B. Salleh, 2004, Lipase-Catalyzed Synthesis of Palm-Based Wax Esters, Journal of Oleo Science, Vol 53, No. 1, 471-477

Gunawan E.R, M. Basri, M.B.A. Rahman, R.N.Z.A. Rahman and A.B. Salleh, 2005, Study on Response Surface Methodology (RSM) of Lipase-Catalyzed Synthesis Of Palm-Based Wax Ester. Enzyme 
Screening dan analisis kadar omega-3... (Erin Ryantin Gunawan dan Dedy Suhendra)

and Microbial Technology Journal, No. 37, 739-744.

http://datakesra.menkokesra.go.id/sites/de fault/files/pendidikan_file/human _developement_index_2011)

M.Jonzo, A. Hiol, I. Zagol, D. Druet, L.C Comeau, ,2000, Microbial Technologi, Vol. 27, No. 6, 443450

Matanjun, P., Mohamed, S. Mustapha, N. \& Muhammad, K, 2009. Nutrient content of tropical edible seaweeds, Eucheuma cottonii, Caulerpa lentillifera and Sargassum polycystum, Journal of Applied Phycology, No. 21, 75-80
Rose, D.P. and Connoly, J.M., 1999, Omega-3 fatty acids as cancer chemopreventive agents, Pharmacology \& Therapeutics, No.83, 217-244

Sax N.I., and R.J Lewis, 1987, "Condensed Chemical Dictionary", Van Nostrand

Suhendra, D., W.M.Z. Wan Yunus, M. HARON, M. Basri dan S. Silong, 2005, Enzymatic Synthesis of Fatty Hydroxamic Acids from Palm Oil, Journal of Oleo Science, Vol.54, No. 1, 33 - 38.

Uauy, R.and Valenzuela, A, 2000, Marine oils: the health benefits of $n-3$ fatty acids, Nutrition, No.16, 680-684 